\title{
Effect of Intermittent Aeration in a Hybrid Vertical Anaerobic Biofilm Reactor (HyVAB) for Reject Water Treatment
}

\author{
Vasan Sivalingam $^{1}{ }^{\mathbb{D}}$, Carlos Dinamarca ${ }^{1, *}$, Eshetu Janka ${ }^{1}$, Sergey Kukankov ${ }^{1}$, Shuai Wang ${ }^{2}$ \\ and Rune Bakke ${ }^{1}$ (D) \\ 1 Department of Process, Energy and Environmental Technology, University of South-Eastern Norway, \\ 3918 Porsgrunn, Norway; vasan.sivalingam@usn.no (V.S.); eshetu.j.wakjera@usn.no (E.J.); \\ kukansn@gmail.com (S.K.); rune.bakke@usn.no (R.B.) \\ 2 Biowater Technology AS, 3115 Tønsberg, Norway; sw@biowatertechnology.com \\ * Correspondence: carlos.dinamarca@usn.no
}

Received: 20 March 2020; Accepted: 14 April 2020; Published: 17 April 2020

\begin{abstract}
Water from anaerobic sludge dewatering (reject water that is recycled to the inlet main process treatment) from the Knarrdalstrand municipal wastewater treatment plant in Porsgrunn, Norway, contains $2.4 \mathrm{~g} / \mathrm{L}$ of total chemical oxygen demand (TCOD) and $550 \mathrm{mg} / \mathrm{L} \mathrm{NH} \mathrm{NH}_{4}-\mathrm{N}$ (annual average). The high concentration of ammonium causes disturbances in the mainstream physical and chemical processes, while only a small fraction of the organics is biodegradable. A pilot-scale hybrid vertical anaerobic biofilm (HyVAB) reactor combining anaerobic and aerobic treatment was tested for reject water treatment to reduce process disturbances. The pilot HyVAB was prepared for the study with continuous aeration of the aerobic part of the reactor for 200 days, while two intermittent aeration schemes were applied during the three-month test period. Ammonium removal efficiency increased from $8 \%$ during the continuous aeration period to $50 \%$ at the end of the test when a short $(7 \mathrm{~min})$ aeration cycle was applied. COD removal was close to $20 \%$, which was mainly obtained in the anaerobic stage and not significantly influenced by the aerations schemes. Simultaneous partial nitrification and denitrification were established in the biofilm that alternated between aerobic and anoxic conditions. The observed high ammonium removal is explained by two alternative shortcut processes via nitrite. The lack of biodegradable organics in the aerated stage suggests that most of the nitrogen removal was via the anammox pathway (autotrophic denitrification). The HyVAB, combining an anaerobic sludge bed and an intermittently aerated biofilm, appears to be an efficient process to treat high ammonium containing reject water.
\end{abstract}

Keywords: reject water; HyVAB reactor; intermittent aeration; nitrogen removal; anammox

\section{Introduction}

Water from the dewatering of anaerobically digested sludge is called reject water. Reject water contains higher concentrations of organic materials, ammonium, and phosphorous than mainstream wastewater [1]. If discharged directly into surface waters, it will cause several environmental and health issues, such as eutrophication [2,3]. Therefore, environmental regulations mandate the treatment of reject water before discharge. Generally, it is mixed with mainstream water near the plant inlet in traditional municipal wastewater treatment plants (WWTP). Recycling reject water into the mainstream is a reasonable approach [4], but it can cause problems. Even though reject water is only about $1-2 \%$ of total mainstream water inflow, it can account for up to $80 \%$ of the nutrient load in the main train process [1]. Ammonium nitrogen presents up to approximately $1500 \mathrm{mg} / \mathrm{L}$ in reject water [5]. Reject water at the Knarrdalstrand wastewater treatment plant (KWWTP) contains on average $550 \mathrm{mg} / \mathrm{L}$ 
ammonium nitrogen, $2400 \mathrm{mg} / \mathrm{L}$ total chemical oxygen demand (TCOD), and $40 \mathrm{mg} / \mathrm{L}$ of phosphorous. During the coagulation and flocculation processes, the phosphorus ion binds strongly with the metal coagulant (i.e., ferric chloride, $\mathrm{FeCl}_{3}$ ), leading to low levels of phosphorous ion concentration in the reject water [6]. Therefore, this research work is mainly focused on ammonium nitrogen and COD removal. The KWWTP treats reject water by recycling it back to the main treatment train as other ordinary municipal WWTPs do.

Reject water is discontinuously generated and released to the inlet. It causes disturbances in the coagulation/flocculation process. Ammonium concentration in reject water is about 30 times higher than the mainstream wastewater. The intermittent release of such strong reject water fluctuates the $\mathrm{pH}$, which in turn affects the coagulation/flocculation time [7], the amount of the coagulant dose, and the stability of the sludge. Reject water contains also a large amount of colloidal organics and solid particles which disturb the coagulation and flocculation processes [8].

Therefore, a pilot hybrid vertical anaerobic biofilm (HyVAB) reactor is used to investigate the treatment of such reject water to improve the overall process stability and performance. Figure 1 shows the flow diagram of the KWWTP, including the position of the reject water treatment process. Although the pilot reactor is connected to the effluent from both the thickener and the centrifuge, only the centrifuged effluent from the anaerobically digested municipal sludge fed the pilot reactor during this research study. Since the centrifuge works intermittently, the reject water is stored in an intermediate bulk container to ensure a continuous supply of feed into the reactor. It treats only a fraction of the reject water.

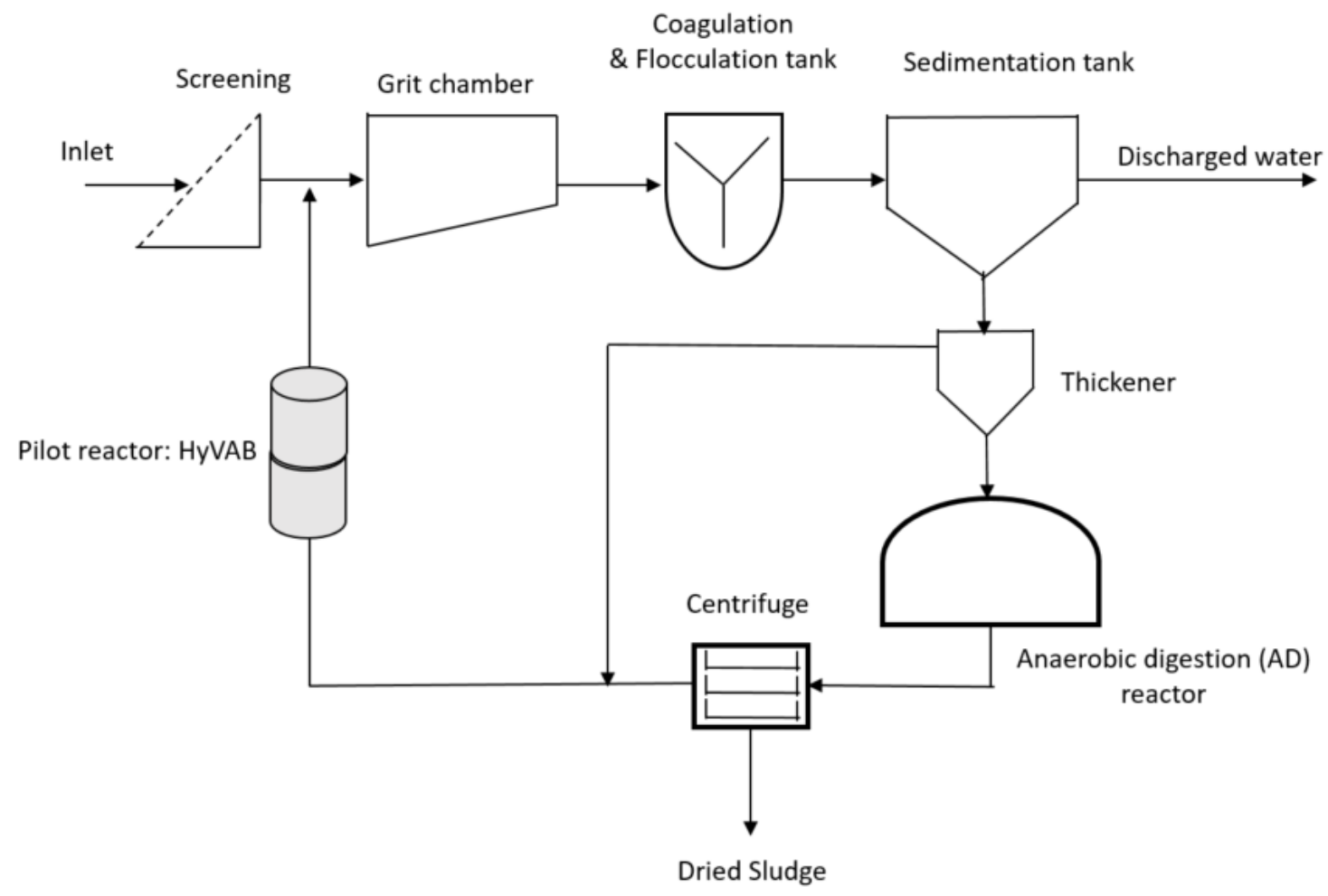

Figure 1. Flow diagram of the Knarrdalstrand wastewater treatment plant (KWWTP) integrated with the pilot hybrid vertical anaerobic biofilm (HyVAB) reactor [9].

There is a need for establishing more efficient reject water treatment where ammonium nitrogen removal is especially important to limit disturbances of the main process when reject water is returned to the plant inlet. A pilot-scale HyVAB reactor for reject water treatment is studied for this purpose with various aeration schemes to evaluate them regarding ammonium removal efficiency. The goal was to evaluate the hypothesis that "nitrogen removal can be enhanced by intermittent aeration to 
obtain both autotrophic and heterotrophic denitrification." This was tested experimentally, and the complete reactor performance was investigated to estimate the overall potential of the HyVAB reactor for reject water treatment.

A biofilm grows on the surface of the biocarriers [10], in this case polyethylene media, referred to as attached biofilm growth $[7,11]$. Biofilm is a mixture of microorganism, particulate material, and extracellular polymers. The diversity depends on nutrient gradient, mutation, genetic regulatory switches, and signaling pathways [7,12]. This research focuses on the effects of oxygen gradient oscillations within biofilms on $\mathrm{NH}_{4}-\mathrm{N}$ removal. Based on the variation in dissolved oxygen concentration in the biofilm, organisms can be mainly classified as aerobic, facultative, and anaerobic organisms. Anaerobic bacteria are mainly present in the depth/closest to the surface of the carrier while aerobic bacteria grow on the top/outermost layer of the biofilm $[13,14]$. A biofilm environment supports the growth of many different types of organisms, and aerobic and anoxic organisms can coexist in the same layers when intermittent aeration is applied.

Aerobic bacteria such as ammonium and nitrite-oxidizing bacteria can be predominant where oxygen is available $[15,16]$. Anaerobic and anoxic reactions occur where free oxygen is unavailable as an electron acceptor. Conventional biological nitrogen removal in wastewater treatment involves aerobic and anoxic compartments. Biofilms can include both the aerobic and anoxic processes in one compartment due to the dissolved oxygen concentration gradient $[10,13,16]$. Process efficiency is, however, mass transfer limited if the oxygen gradient is stable, which is often the case when continuous aeration is applied. The main aim of this study is to investigate whether intermittent aeration can reduce this limitation by imposing temporal oxygen gradient changes. The hypothesis is that a significant portion of the biofilm will alternate between ammonium oxidation and denitrification during the aeration cycles. The ammonium oxidation products $\left(\mathrm{NO}_{2}\right.$ and $\left.\mathrm{NO}_{3}\right)$ may thereby be removed by autotrophic or heterotrophic denitrification in the same biofilm layers where they are produced, avoiding the rate-limiting diffusion between layers. The investigated process includes a first anaerobic stage to convert easily degradable organics into methane, which is presumably favorable for the following nitrogen removal in the aerated biofilm stage.

\section{Theory}

\subsection{Traditional Nitrogen Removal}

Dissolved nitrogen in wastewater mainly exists in the form of ammonium $\left(\mathrm{NH}_{4}^{+}\right)$. Firstly, ammonium is converted to nitrite (termed nitritation) [16] autotrophically by ammonium oxidizing bacteria (AOB, Equation (1)) followed by nitrite conversion to nitrate by nitrite-oxidizing bacteria (NOB, Equation (2)) [7,16]. This two stage ammonium conversion to nitrate is referred to as nitrification [17].

$$
\begin{gathered}
2 \mathrm{NH}_{4}^{+}+3 \mathrm{O}_{2} \stackrel{\mathrm{AOB}}{\longrightarrow} 2 \mathrm{NO}_{2}^{-}+4 \mathrm{H}^{+}+2 \mathrm{H}_{2} \mathrm{O} \\
2 \mathrm{NO}_{2}^{-}+\mathrm{O}_{2} \stackrel{\mathrm{NOB}}{\longrightarrow} 2 \mathrm{NO}_{3}^{-}
\end{gathered}
$$

The produced nitrate is reduced to nitrogen gas (denitrification) through a succession of four steps (Figure 2) by heterotrophic bacteria. Organic matter is the reducing agent, here denoted as $\mathrm{C}_{10} \mathrm{H}_{19} \mathrm{O}_{3} \mathrm{~N}$ that results in the overall generalized Equation (3) [7,17].

$$
\mathrm{C}_{10} \mathrm{H}_{19} \mathrm{O}_{3} \mathrm{~N}+10 \mathrm{NO}_{3}^{-} \rightarrow 5 \mathrm{~N}_{2}+10 \mathrm{CO}_{2}+3 \mathrm{H}_{2} \mathrm{O}+\mathrm{NH}_{3}+10 \mathrm{OH}^{-}
$$




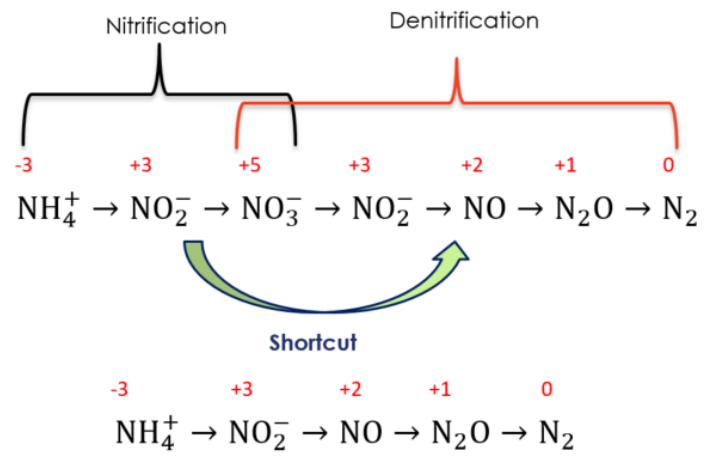

Figure 2. Nitrification, denitrification, and the shortcut mechanism illustrated with oxidation states of nitrogen.

\subsection{Shortcut to Traditional Biological Nitrogen Removal}

Both nitrification and denitrification pass through nitrite, and thus, short-circuiting these processes is possible as illustrated in Figure 2. That means that oxidation of nitrite to nitrate is suppressed, and nitrite is directly reduced to nitric oxide (NO) and subsequently reduced to nitrogen gas [7].

The anammox process, performed by autotropic bacteria, is more direct and requires less energy than traditional nitrogen removal [7]: Ammonium serves as the electron donor for autotrophic denitrification with nitrite as an electron acceptor (Equation (4)).

$$
\mathrm{NH}_{4}^{+}+\mathrm{NO}_{2}^{-} \rightarrow \mathrm{N}_{2}+2 \mathrm{H}_{2} \mathrm{O}
$$

Nitrification and denitrification are normally carried out in two separate compartments in both heterotrophic and autotrophic denitrification schemes. Both reactions can, however, occur within biofilms in a single compartment, and intermittent aeration can be applied to enhance them, presumably to achieve partial nitritation/anammox within a single biofilm layer. This is intended to reduce both capital and operational costs of the treatment process [18] as it minimizes mechanical complexity and aeration costs [17].

Dissolved oxygen (DO) dynamics can be controlled by either a proportional-integral-derivative (PID) controller using DO concentration measurements and DO set point levels or by a timer-based aeration on/off control. Figure 3 shows typical DO profile changes with intermittent aeration and defines the aeration fraction $(\mathrm{AF})$ and the aeration cycle (AC), which are the key parameters in intermittent aeration. The figure also illustrates how the oxygen utilization rate (OUR) can be monitored by measured changes in the bulk liquid DO levels. Nitrification is favored at the higher DO levels, while denitrification takes mainly place when the DO is low (anoxic) [19]. 


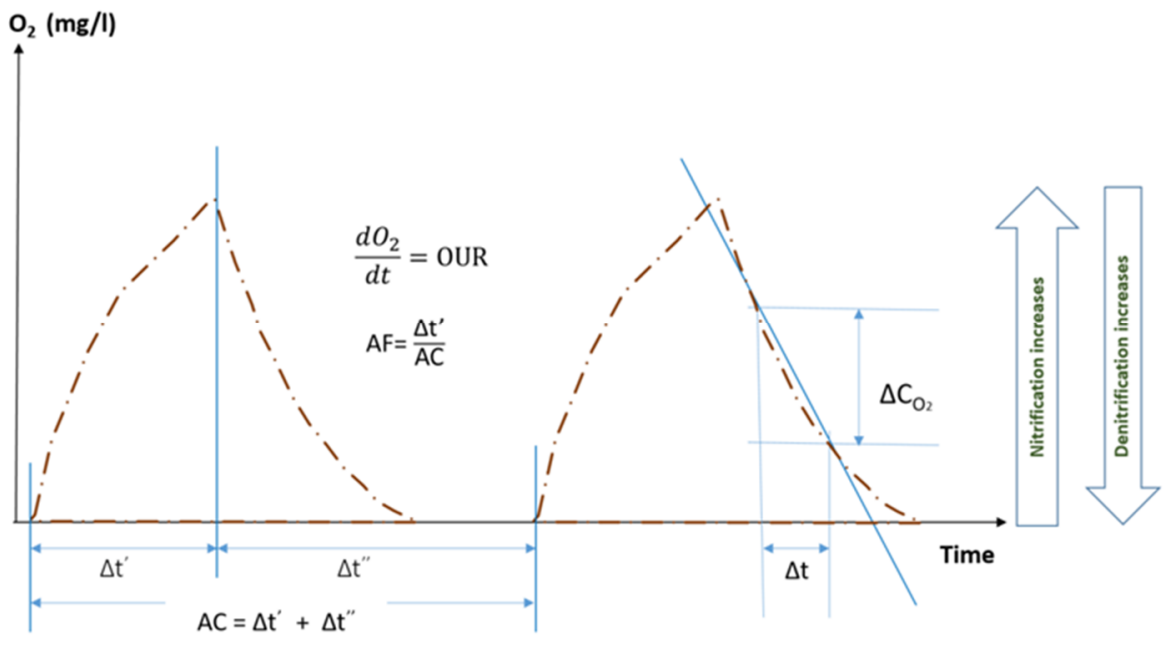

Figure 3. Dissolved oxygen (DO) profile during intermittent aeration (AF = Aeration fraction, $\mathrm{AC}=$ Aeration cycle, $\mathrm{OUR}=$ Oxygen utilization rate) $[20]$.

\section{Materials and Methods}

Figure 4 shows the layout of the HyVAB reactor. The reactor is divided into two major components: Water enters into the upflow anaerobic sludge bed section (i.e., lower compartment) and flows up into the aerated top section. The aerated section can be operated either as continuous flow intermittent cleaning biofilm (CFIC ${ }^{\circledR}$, (Biowater Technology AS, Tønsberg, Norway)) or as moving bed biofilm processes [21-23]. A gas separator between the anaerobic and aerobic parts collects biogas while water flows upwards. The upper part is packed with carriers and is aerated continuously or intermittently. The reactor was in operation for more than 200 days with continuous aeration before this project started. Ammonium, TCOD and soluble chemical oxygen demand (SCOD) removal during this preparation period prior to the experimental study presented here were around $8 \%, 16 \%$, and $20 \%$, respectively. Two intermittent aeration schemes were applied during the 3-month test period (200-292 days). Only experimental results obtained between the 200th day and 292nd day of the HyVAB operation on reject water as feed are taken into account for this study. The recycling rate for the anaerobic section was constant during the experiment (feeding: recycling flows ratio was 1:3) to fluidize the granular sludge bed. The hydraulic retention time (HRT) was constant at 16 hours. The total working volume and water depth of the aerobic part were $43.2 \mathrm{~L}$ and $1.56 \mathrm{~m}$, respectively. Approximately $70 \%$ of the aerobic section was filled with BWT15 ${ }^{\circledR}$ (Biowater Technology AS, Tønsberg, Norway) type carriers (dimension: $14.5 \times 14.5 \times 5 \mathrm{~mm}$, protected surface area: $828 \mathrm{~m}^{2} / \mathrm{m}^{3}$ ), as seen in Figure 4 . Table 1 lists the reactor design parameters and operational conditions separately for the aerobic and anaerobic sections. 


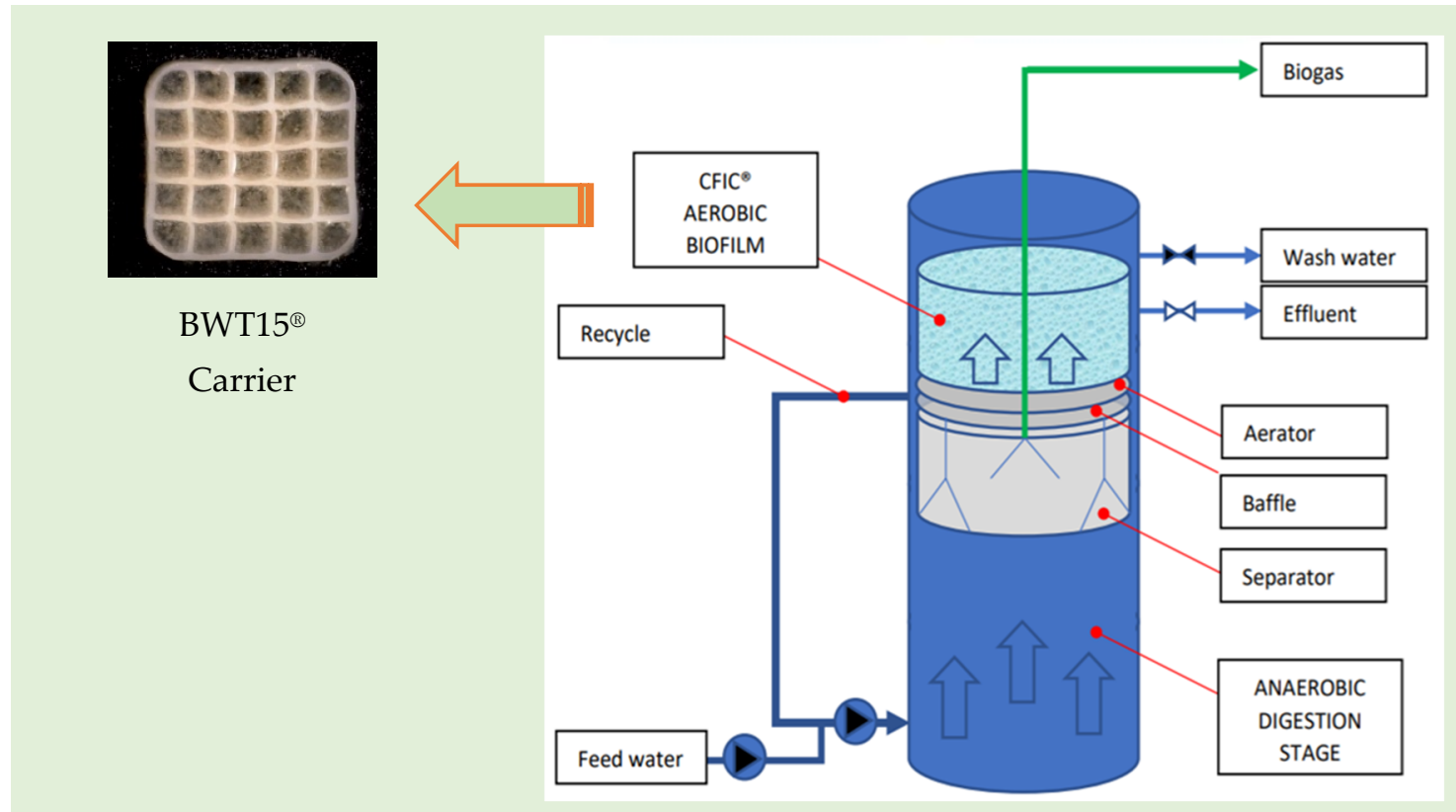

Figure 4. Layout of the HyVAB reactor setup and image of the carrier used in HyVAB [21].

Table 1. HyVAB reactor design parameters and operational conditions.

\begin{tabular}{|c|c|c|c|c|c|}
\hline Parameter & Unit & Value & Parameter & Unit & Value \\
\hline \multicolumn{3}{|c|}{ Anaerobic section } & \multicolumn{3}{|c|}{ Aerobic section } \\
\hline Total volume & $\mathrm{L}$ & 21.6 & Total volume & $\mathrm{L}$ & 21.6 \\
\hline Temperature & ${ }^{\circ} \mathrm{C}$ & $35 \pm 2$ & Temperature & ${ }^{\circ} \mathrm{C}$ & $30 \pm 2$ \\
\hline Granular sludge bed volume & $\mathrm{L}$ & 18.7 & Cross-sectional area & $\mathrm{m}^{2}$ & 0.018 \\
\hline Water depth & $\mathrm{m}$ & 1.0 & Type of media & & BWT15 ${ }^{\circledR}$ \\
\hline Cross-sectional area & $\mathrm{m}^{2}$ & 0.016 & Carriers filled & $\mathrm{L}$ & 16.3 \\
\hline Upflow velocity & $\mathrm{m} / \mathrm{h}$ & 0.675 & Number of carriers filled & No & 1332 \\
\hline Internal diameter & $\mathrm{cm}$ & 14.2 & Total protected surface area & $\mathrm{m}^{2}$ & 10.5 \\
\hline Gas baffle diameter & $\mathrm{mm}$ & 82 & & & \\
\hline
\end{tabular}

\subsection{Analysis Methodology}

A proportional-integral-derivative (PID) temperature controller device was used to keep the aerobic part temperature constant at $30 \pm 2{ }^{\circ} \mathrm{C}$. Aeration was controlled using an on/off controller. DO was measured by WTW Oxi 3310 and MultiLine ${ }^{\circledR} 3620$ IDS DO meters. Samples were collected from the HyVAB reactor's inlet, the anaerobic digestion (AD) part outlet, and the aerobic part outlet twice a week. The pH was measured by a pH-meter (Beckman 390, Beckman Instruments, Indianapolis, IN, USA). The organic content was measured by three different parameters: TCOD, SCOD, and ultimate biological oxygen demand (UBOD). TCOD and SCOD analyses were performed according to the APHA 5220D standard [24]. UBOD was measured based on the standard method 5210 C [24]. Nitrogen species, such as nitrate, ammonium, and nitrite concentrations, and alkalinity were measured by the Spectroquant ${ }^{\circledR}$ Pharo 300 UV/VIS photometer (Merck KGaA, Darmstadt, Germany) according to the standard methods of the America Public Health Association (APHA 1995) [24]. The oxidation reduction potential (ORP) of the AD part was measured by the ORP meter (HI991003 $\mathrm{pH} / \mathrm{pH}-\mathrm{mV} / \mathrm{ORP} /$ Temperature Meter with Sensor Check $^{\mathrm{TM}}$ ) to check whether the AD reduction potential was in the right range for biomethane generation. A Nikon Stereo Microscope SMZ745T was used to observe both the granular morphology and the biofilm thickness on biocarriers. Biofilm thickness was measured in different locations on the biocarries by the Infinity Analyze software. 


\subsection{Aeration Control in the HyVAB Reactor}

Timer-based aeration control by the Arduino microcontroller was tuned to achieve the desired oxygen profile (Figure 3). A 20-min AC, $5 \mathrm{~min}$ on/15 min off was tested first, and a $7 \mathrm{~min}$ AC, $3 \mathrm{~min}$ on/4 min off cycle was tested in the second trial (Table 2). Trial 1 was started on the 202nd day and Trial 2 started on 257 th day.

Table 2. Intermittent aeration cycle trials and aeration fraction details.

\begin{tabular}{cccc}
\hline Trial No. & Aeration Cycle (min) & Aeration Fraction & Duration (Days) \\
\hline 1 & 20 & 0.75 & 48 \\
2 & 7 & 0.43 & 35 \\
\hline
\end{tabular}

\section{Results and Discussion}

\subsection{Dissolved Oxygen, Organics, and Nitrogen Species Profile}

In Trial $1(\mathrm{AC}=20, \mathrm{AF}=0.75)$, the $\mathrm{DO}$ concentration range decreased from $2-6 \mathrm{mg} / \mathrm{L}$ at the beginning to $0.2-5 \mathrm{mg} / \mathrm{L}$ at the end of the trial (Figure 5). No significant removal of ammonium was measured during Trial 1, while $\sim 20 \%$ total and soluble COD removal was established early and maintained throughout (Figure 7). In Trial $2(\mathrm{AC}=7, \mathrm{AF}=0.43)$, the $\mathrm{DO}$ concentration range decreased from $2.5-5.5 \mathrm{mg} / \mathrm{L}$ at the beginning to $1.5-4.7 \mathrm{mg} / \mathrm{L}$ at the end of the trial (Figure 6), implying increased endogenous oxygen utilization.
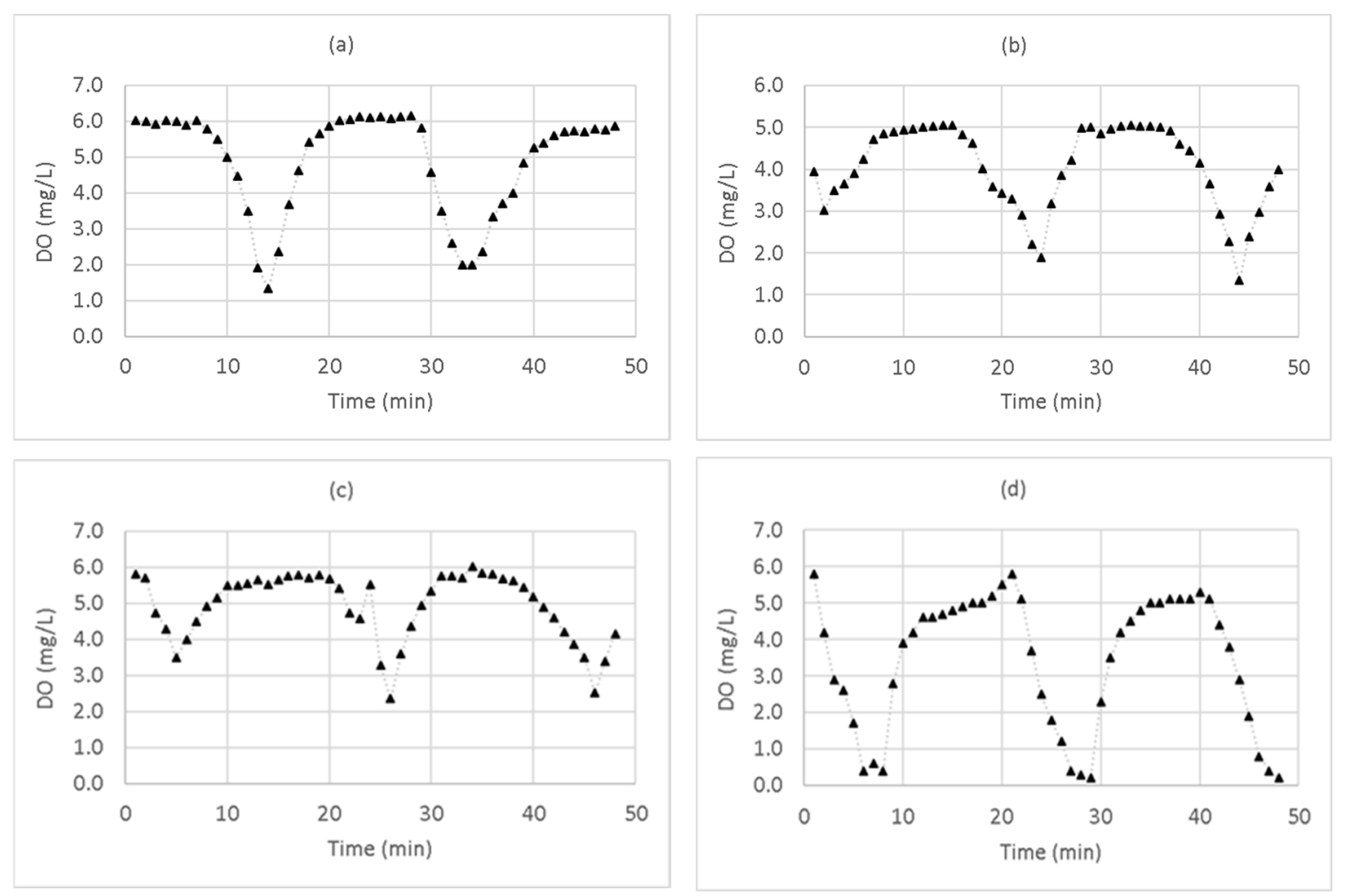

Figure 5. DO concentration variation in the HyVAB for Trial 1: (a) DO profile on the 237th day, (b) DO profile on the 241st day, (c) DO profile on the 247th day, and (d) DO profile on the 251st day. 

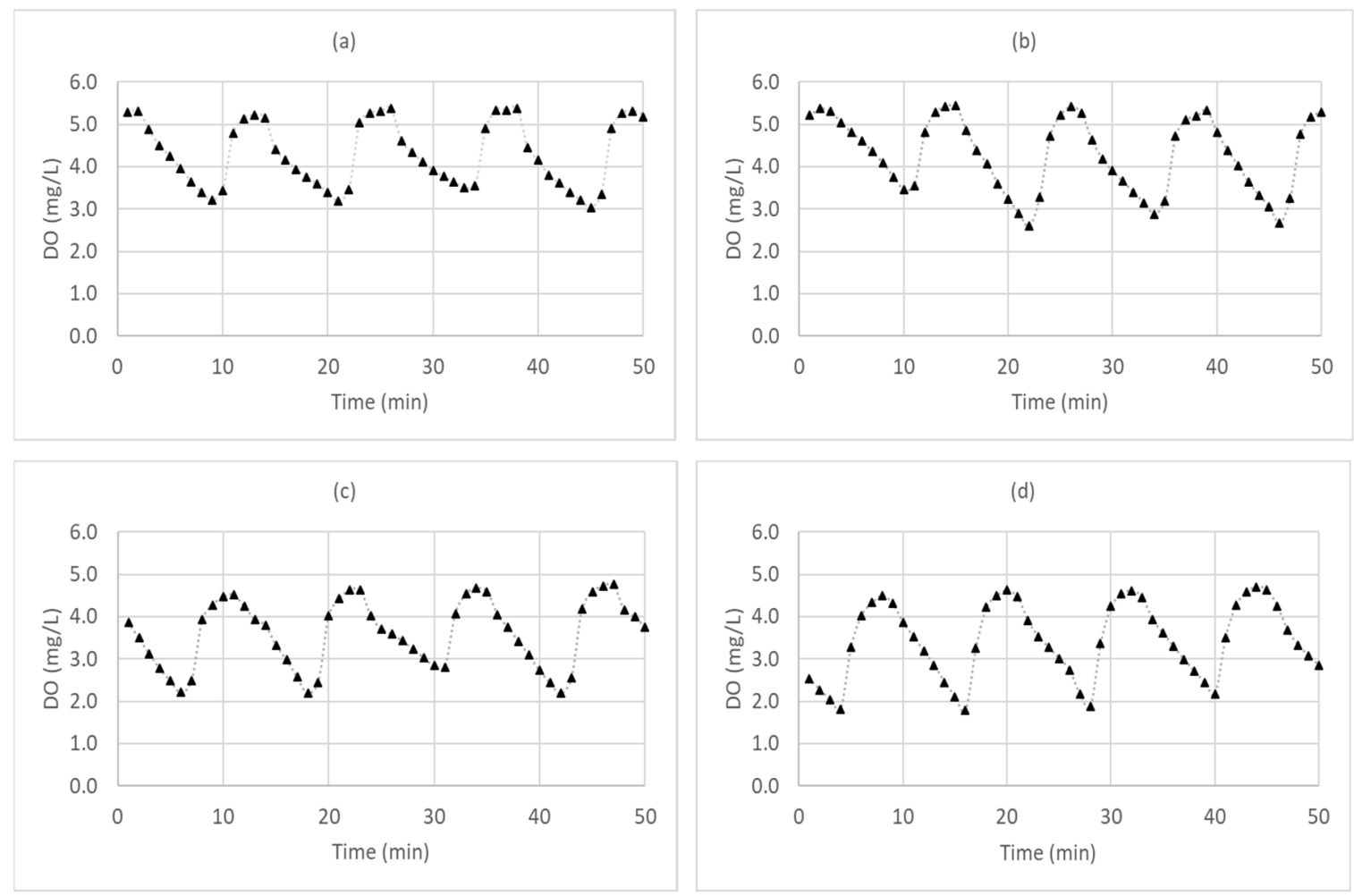

Figure 6. DO concentration variation in the HyVAB for Trial 2: (a) DO profile on the 262nd day, (b) DO profile on the 264th day, (c) DO profile on the 292nd day, and (d) DO profile on the 295th day.

TCOD removal varied, and the variations diminished towards the end of the experiment (Figure 7A). The influent average TCOD was $2.5 \mathrm{~g} / \mathrm{L}$, and $20 \%$ was removed. Most of the COD removal occurred in the AD section, and no net SCOD removal was observed in the aerated biofilm compartment. The outlet SCOD average $1.2 \mathrm{~g} / \mathrm{L}$, which was $20 \%$ less than inlet concentration (Figure $7 \mathrm{~B}$ ). The low COD removal is explained by low levels of biodegradable organics in the reject water. This is reasonable because the KWWTP's AD reactors utilize most of the BOD for biogas production. The measured reject water $\mathrm{UBOD}=90 \mathrm{mg} / \mathrm{L}$ confirms this, as does the observed lack of biogas production. Measured ORP was between -330 and $-360 \mathrm{mV}$, and observed granular sludge morphology via the stereomicroscope (Figure 10B) shows the appropriate conditions for biomethane production prevailed [25], but methane levels remained below saturation. 

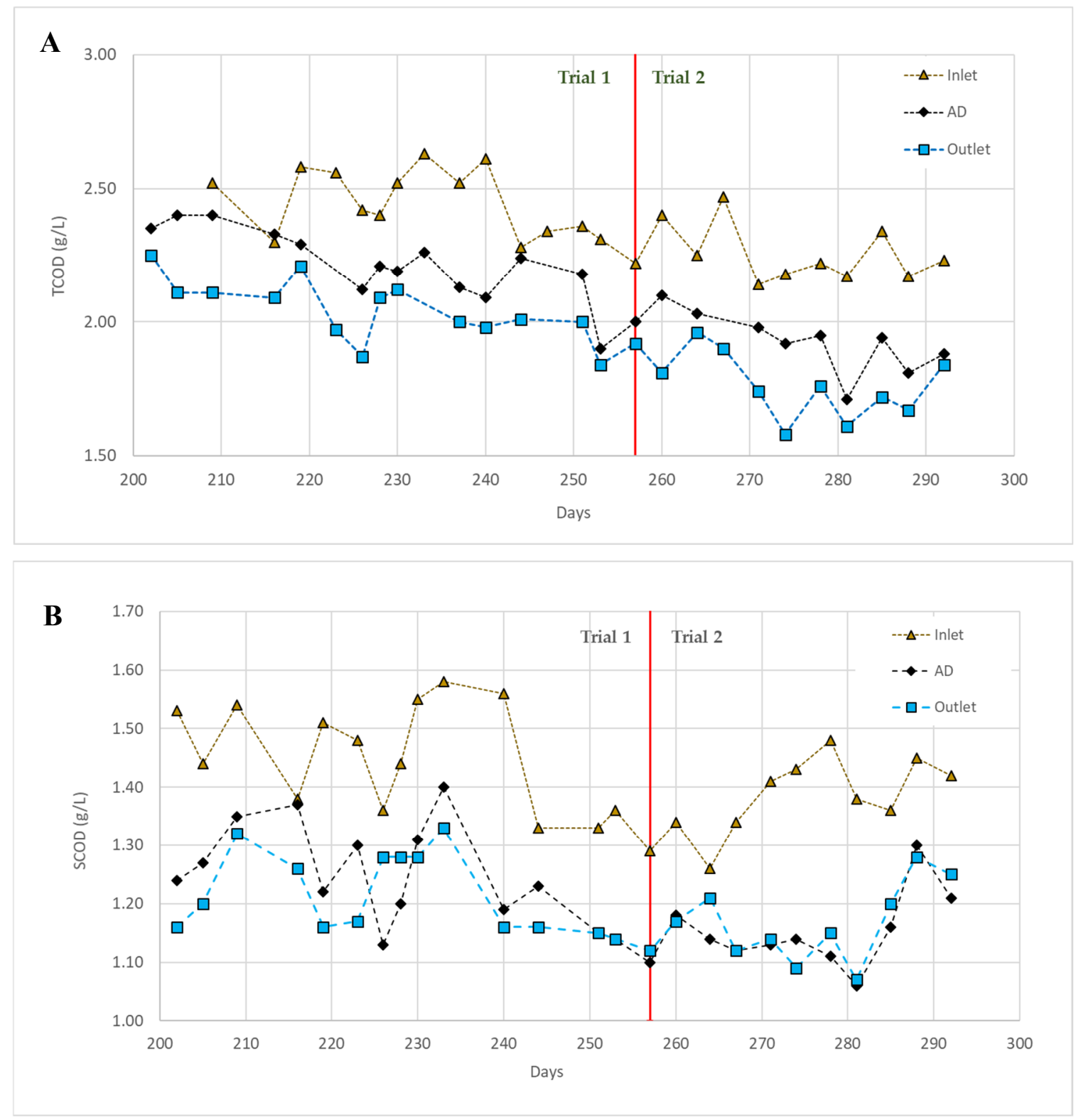

Figure 7. Inlet, anaerobic digestion (AD), and outlet concentration of total chemical oxygen demand (TCOD) (A) and soluble chemical oxygen demand (SCOD) (B).

Measured nitrogen species concentrations in the aerobic part of the HyVAB reactor and influent ammonium concentrations are given in Figure 8. Nitrate and nitrite concentrations increased, while reactor ammonium concentration fell after the 235th day. The nitrite concentration increased from 5 to $50 \mathrm{mg} / \mathrm{L}$, while nitrate concentration only gradually increased from 5 to $15 \mathrm{mg} / \mathrm{L}$. Approximately $50 \%$ ammonium removal was attained at the end of Trial 2 . About $20 \%$ of this accumulated as nitrite, $4 \%$ as nitrate, implying that approximately $3 / 4$ of removed ammonium was denitrified. The high nitrite to nitrate ratio is favorable for the abovementioned shortcut nitrogen removal processes [7]. Nitrite oxidation can be suppressed by shorter aeration cycles [26], and accumulated nitrite can be reduced with ammonium ion as the electron donor (Anammox). Such shortcut mechanisms can increase the nitrogen removal efficiency $[17,27]$. 


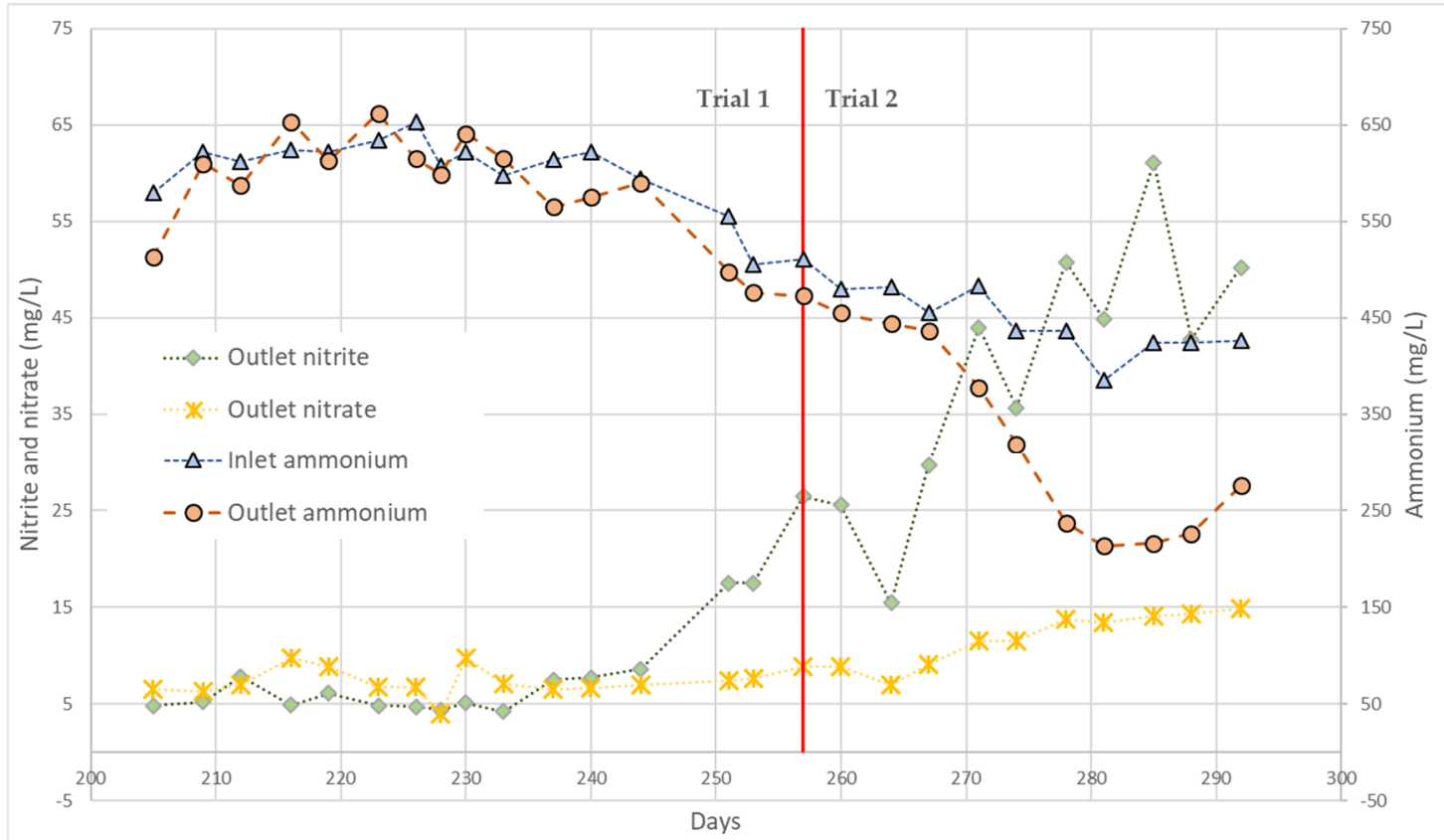

Figure 8. Nitrogen species variation in the HyVAB reactor.

The heterotrophic shortcut process requires $40 \%$ less organic carbon for denitrification than the traditional denitrification process, and the anammox process requires no organic carbon for denitrification. Both options require less oxygen and alkalinity than traditional denitrification (e.g., 25\% reduced aeration demand [7]). These shortcut processes likely dominate the observed nitrogen removal. The lack of biodegradable organics in the aerated stage suggests that most of the nitrogen removal was via the anammox pathway. The TCOD, SCOD, and ammonium removal trends given in Figure 9 support the assumption that the HyVAB process with intermittent aeration is efficient for reject water treatment.

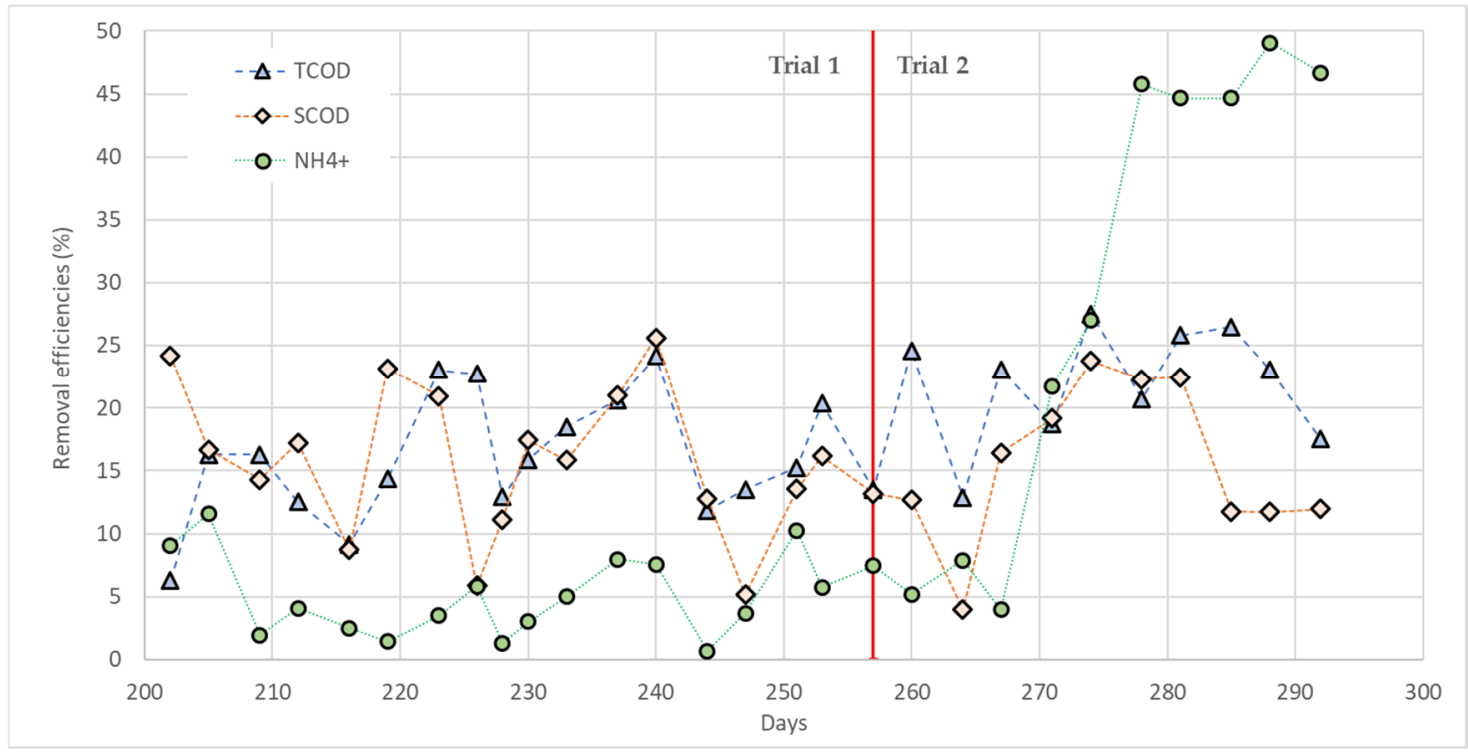

Figure 9. TCOD, SCOD, and $\mathrm{NH}_{4}{ }^{+}$removal efficiencies in the HyVAB reactor. 


\subsection{Stereo Microscopic Images}

Figure 10A shows a stereo microscopic image of a biocarrier (BWT15 $\left.{ }^{\circledR}\right)$. The biofilm thickness, Lf, was measured from such images in different locations of the carriers (as illustrated in the image), finding an average $\mathrm{Lf}=77 \pm 26 \mu \mathrm{m}(\mathrm{n}=10)$. Figure 10B shows a stereo microscopic image of the anaerobic granular sludge. The granules had well-defined, spherical morphology with the diameter, $\mathrm{L}$, less than $1 \mathrm{~mm}(\mathrm{~L}=525 \pm 180 \mu \mathrm{m}(\mathrm{n}=10))$.

(A)

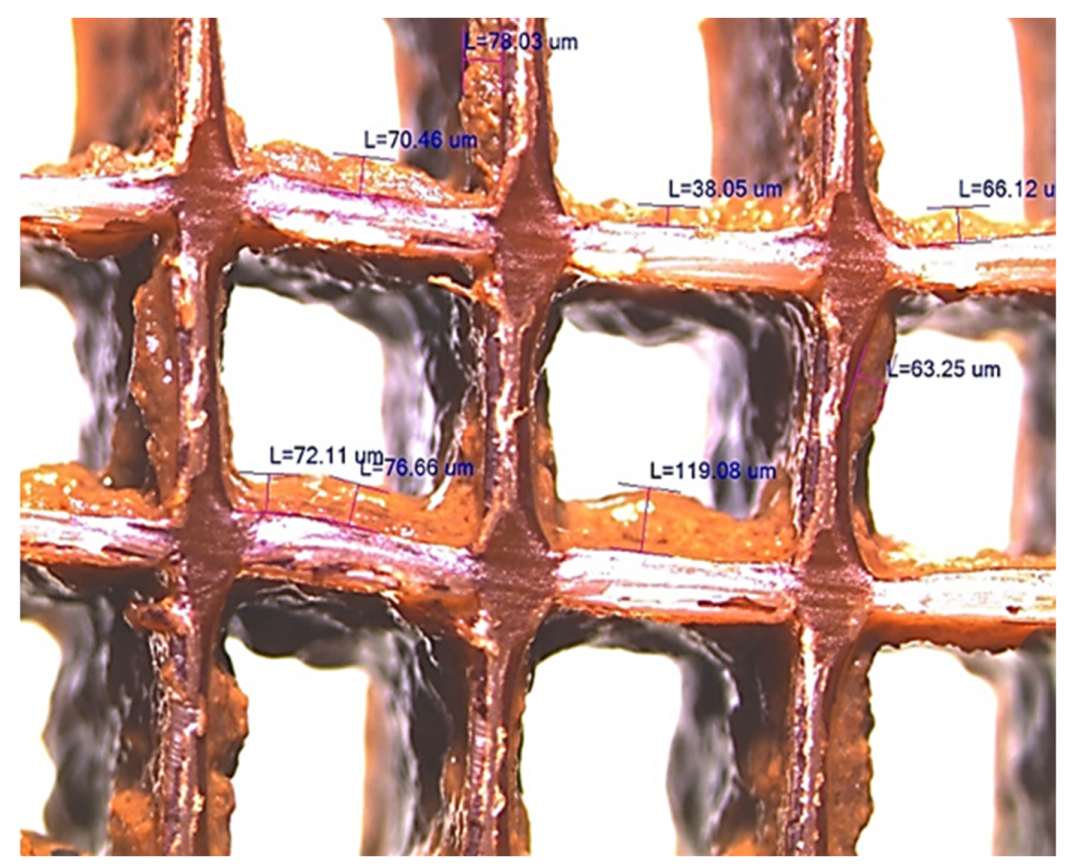

(B)

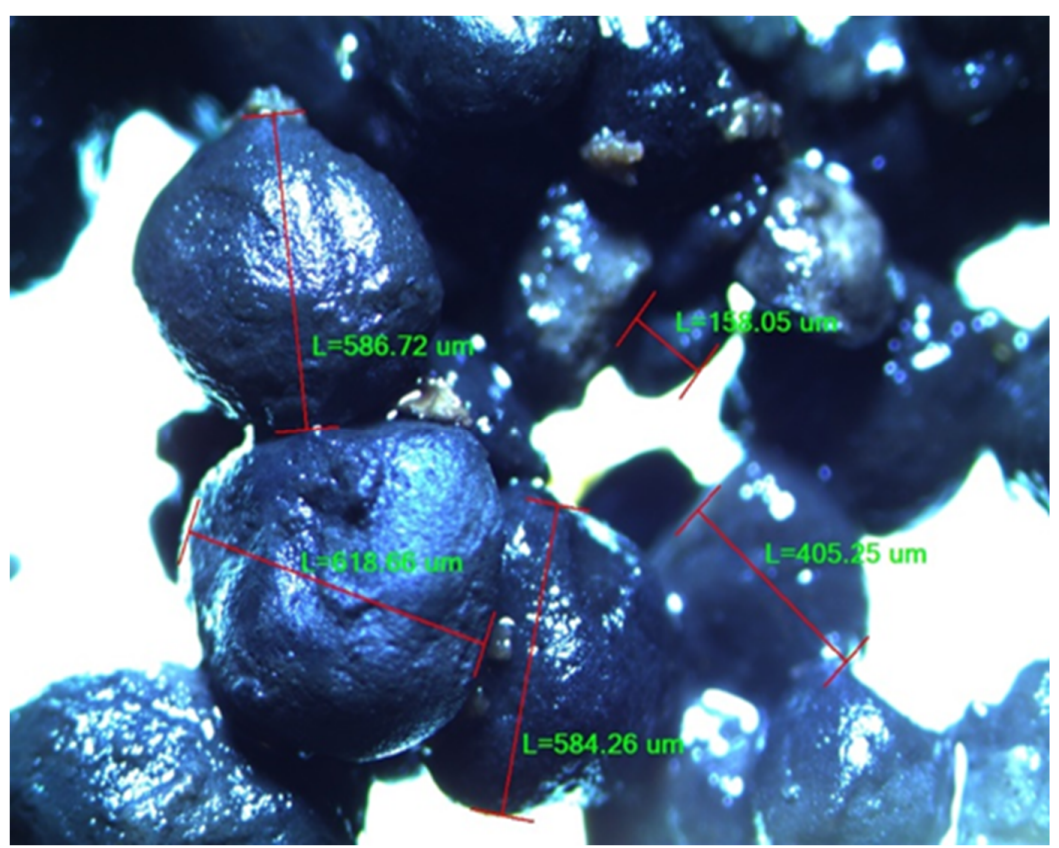

Figure 10. Stereo microscopic images captured via the Infinity Lumenera camera and measured by the Infinity Analyze software: (A) A HyVAB carrier (grid size; $500 \times 500 \mu \mathrm{m}$ ) and (B) the HyVAB AD granular sludge (scale shown as diameters (L) of granules). 


\section{Conclusions}

The HyVAB reactor with a short, intermittent aeration cycle of 7 min efficiently treated reject water from anaerobically treated sludge at a domestic wastewater treatment plant. The lack of biodegradable organics was identified as the limiting factor for traditional biological nitrogen removal. Most of the HyVAB's organics removal (20\% of reject water COD) occurred in its anaerobic stage, and the aerated biofilm stage removed nitrogen. Ammonium removal efficiency raised from $8 \%$ during the continuous aeration period to $50 \%$ at the end of the study, of which approximately $3 / 4$ was denitrified. Shortcut processes via nitrite dominate the observed nitrogen removal, and the lack of biodegradable organics in the aerated stage may suggest that most of the nitrogen removal was via the anammox pathway (autotrophic denitrification).

Author Contributions: Conceptualization, R.B., S.W., and C.D.; Data curation, V.S.; Formal analysis, V.S. and S.K.; Funding acquisition, S.W. and R.B.; Investigation, V.S., C.D., and R.B.; Methodology, V.S., E.J., and S.W.; Project administration \& Resources, C.D.; Software, S.K.; Supervision, C.D., E.J., S.W., and R.B.; Validation, C.D., E.J., S.W., and R.B.; Visualization, V.S.; Writing—original draft, V.S.; Writing—review and editing, V.S., C.D., E.J., S.W., and R.B. All authors have read and agreed to the published version of the manuscript.

Funding: The research project "Efficient upgrading of municipal wastewater treatment plants (Project No: 269014)" was funded by the Research Council of Norway's "Oslofjordfondet". The APC was funded by the University of South-Eastern Norway.

Acknowledgments: Authors want to thank the Knarrdalstrand wastewater treatment plant in Porsgrunn, Norway for supporting the pilot study.

Conflicts of Interest: The authors declare no conflict of interest.

\section{References}

1. Guo, C.H.; Stabnikov, V.; Ivanov, V. The removal of nitrogen and phosphorus from reject water of municipal wastewater treatment plant using ferric and nitrate bioreductions. Bioresour. Technol. 2010, 101, 3992-3999. [CrossRef] [PubMed]

2. Nyenje, P.; Foppen, J.W.; Uhlenbrook, S.; Kulabako, R.; Muwanga, A. Eutrophication and nutrient release in urban areas of sub-Saharan Africa: A review. Sci. Total Environ. 2010, 408, 447-455. [CrossRef] [PubMed]

3. Zhang, S.; Wang, Y.; He, W.; Wu, M.; Xing, M.; Yang, J.; Gao, N.; Yin, D. Responses of biofilm characteristics to variations in temperature and $\mathrm{NH}_{4}{ }^{+}-\mathrm{N}$ loading in a moving-bed biofilm reactor treating micro-polluted raw water. Bioresour. Technol. 2013, 131, 365-373. [CrossRef] [PubMed]

4. Jones, R.M.; Dold, P.L.; Takács, I.; Chapman, K.; Wett, B.; Murthy, S.; Shaughnessy, M. Simulation for operation and control of reject water treatment processes. Proc. Water Environ. Fed. 2007, 2007, 4357-4372. [CrossRef]

5. Berends, D.; Salem, S.; Van Der Roest, H.; Van Loosdrecht, M. Boosting nitrification with the BABE technology. Water Sci. Technol. 2005, 52, 63-70. [CrossRef] [PubMed]

6. Niazi, S. Coagulation Effects of Biological Sludge Reject Water Treatment. Master's Thesis, University of South-Eastern Norway, Porsgrunn, Norway, May 2018.

7. Tchobanoglous, G.; Burton, F.L.; Stensel, H.D. Wastewater Engineering: Treatment and Resource Recovery; McGraw-Hill Higher Education: New York, NY, USA, 2014.

8. Hashemi, S. Biological Reject Water Treatment by Using Moving Bed Biofilm Reactors (MBBR). Master's Thesis, University of South-Eastern Norway, Porsgrunn, Norway, May 2018.

9. Sivalingam, V.; Ibrahim, O.; Kukankov, S.; Omodara, B.; Janka, E.; Wang, S.; Dinamarca, C.; Haugen, H.; Bakke, R. Chemical equilibrium model to investigate scaling in moving bed biofilm reactors (MBBR). In Proceedings of the 60th SIMS Conference on Simulation and Modelling SIMS 2019, Vasteras, Sweden, 12-16 August 2019; Linkoping University Electronic Press: Linkoping, Sweden, 2020; pp. 139-144.

10. Barwal, A.; Chaudhary, R. To study the performance of biocarriers in moving bed biofilm reactor (MBBR) technology and kinetics of biofilm for retrofitting the existing aerobic treatment systems: A review. Rev. Environ. Sci. Bio/Technol. 2014, 13, 285-299. [CrossRef]

11. Davey, M.E.; O'toole, G.A. Microbial biofilms: From ecology to molecular genetics. Microbiol. Mol. Biol. Rev. MMBR 2000, 64, 847-867. [CrossRef] 
12. Flemming, H.-C.; Wingender, J.; Szewzyk, U.; Steinberg, P.; Rice, S.A.; Kjelleberg, S. Biofilms: An emergent form of bacterial life. Nat. Rev. Microbiol. 2016, 14, 563-575. [CrossRef]

13. Piculell, M. New Dimensions of Moving Bed Biofilm Carriers: Influence of Biofilm Thickness and Control Possibilities; Lund University: Lund, Sweden, 2016.

14. Almstrand, R.; Persson, F.; Daims, H.; Ekenberg, M.; Christensson, M.; Wilén, B.-M.; Sorensson, F.; Hermansson, M. Three-dimensional stratification of bacterial biofilm populations in a moving bed biofilm reactor for nitritation-anammox. Int. J. Mol. Sci. 2014, 15, 2191-2206. [CrossRef]

15. Sliekers, A.O.; Haaijer, S.C.M.; Stafsnes, M.H.; Kuenen, J.G.; Jetten, M.S.M. Competition and coexistence of aerobic ammonium- and nitrite-oxidizing bacteria at low oxygen concentrations. Appl. Microbiol. Biotechnol. 2005, 68, 808-817. [CrossRef]

16. Odegaard, H. A road-map for energy-neutral wastewater treatment plants of the future based on compact technologies (including MBBR). Front. Environ. Sci. Eng. 2016, 10, 2. [CrossRef]

17. Ruiz, G.; Jeison, D.; Rubilar, O.; Ciudad, G.; Chamy, R. Nitrification-denitrification via nitrite accumulation for nitrogen removal from wastewaters. Bioresour. Technol. 2006, 97, 330-335. [CrossRef]

18. Yang, J.; Trela, J.; Zubrowska-Sudol, M.; Plaza, E. Intermittent aeration in one-stage partial nitritation/anammox process. Ecol. Eng. 2015, 75, 413-420. [CrossRef]

19. Cowman, J.; Torres, C.I.; Rittmann, B.E. Total nitrogen removal in an aerobic/anoxic membrane biofilm reactor system. Water Sci. Technol. 2005, 52, 115-120. [CrossRef]

20. Bakke, R. High Tech Process in Combination with Natural Systems. M.Sc Lecture presentation, University of South-Eastern Norway, Porsgrunn, Norway, 2018.

21. HyVAB. Biowater Technology. Available online: https://www.biowatertechnology.com/en/technology/hyvab/ (accessed on 9 March 2020).

22. Wang, S.; Savva, I.; Bakke, R. A full-scale hybrid vertical anaerobic and aerobic biofilm wastewater treatment system: case study. Water Pract. Technol. 2019, 14, 189-197. [CrossRef]

23. Janka, E.; Carvajal, D.; Wang, S.; Bakke, R.; Dinamarca, C. Treatment of Metformin-Containing Wastewater by a Hybrid Vertical Anaerobic Biofilm-Reactor (HyVAB). Int. J. Environ. Res. Public Health 2019, 16, 4125. [CrossRef] [PubMed]

24. APHA. Standard Methods for the Examination of Water and Wastewater; American Public Health Association, American Water Works Association and Water Environment Federation: Washington, DC, USA, 1995.

25. Tassew, F.A.; Bergland, W.H.; Dinamarca, C.; Kommedal, R.; Bakke, R. Granular Sludge Bed Processes in Anaerobic Digestion of Particle-Rich Substrates. Energies 2019, 12, 2940. [CrossRef]

26. Mota, C.; Head, M.A.; Ridenoure, J.A.; Cheng, J.J.; Reyes, F.L. Effects of Aeration Cycles on Nitrifying Bacterial Populations and Nitrogen Removal in Intermittently Aerated Reactors. Appl. Environ. Microbiol. 2005, 71, 8565-8572. [CrossRef] [PubMed]

27. Li, J.; Li, J.; Gao, R.; Wang, M.; Yang, L.; Wang, X.; Zhang, L.; Peng, Y. A critical review of one-stage anammox processes for treating industrial wastewater: optimization strategies based on key functional microorganisms. Bioresour. Technol. 2018, 265, 498-505. [CrossRef] [PubMed]

(C) 2020 by the authors. Licensee MDPI, Basel, Switzerland. This article is an open access article distributed under the terms and conditions of the Creative Commons Attribution (CC BY) license (http://creativecommons.org/licenses/by/4.0/). 